\title{
Los responsables de la muerte de Jesús
}

\author{
Xavier Alegre, \\ Facultad de Teología de Cataluña, \\ Centro de Reflexión Teológica, San Salvador.
}

\section{Planteamiento de la cuestión}

\subsection{Actualidad del tema}

Desde la ventana de mi despacho en el Centro Monseñor Romero contemplo cada día el "Jardín de rosas" que plantó don Obdulio, el marido de Elba y padre de Celina, en recuerdo de los mártires de la UCA. Y veo a menudo numerosos grupos que peregrinan al lugar en que fueron asesinados. Estoy en el Centro Monseñor Romero, un lugar que quiere mantener viva la memoria de ese salvadoreño universal, Monseñor Romero, que, como "buen pastor", supo estar, como Jesús, al lado y del lado de su pueblo empobrecido y marginado hasta dar su vida generosamente por él.

No han pasado dos mil años, como han pasado ya desde que el primer mártir cristiano, Jesús de Nazaret, dio su vida en una cruz. Pero el tiempo difumina los recuerdos y los diferentes intereses creados dificultan la comprensión del significado de su muerte y la identificación clara de quiénes fueron los responsables de la misma. No resulta fácil, por lo general, mantener viva la memoria de los mártires y "ponerla a producir", como suele decir Jon Sobrino. Ya ocurrió con Jesús de Nazaret. Al fin y al cabo, los evangelios son, entre otras cosas, un esfuerzo, ciertamente inspirado por Dios, por mantener viva la memoria del primer mártir cristiano (cfr. Ap 1,5 ) y por ponerla a producir. Pero no fue tarea fácil. $Y$, hoy como ayer, resulta difícil aproximarse a la verdad "histórica". Pero vale la pena intentarlo, pues puede resultar iluminadora para nuestra aproximación a la historia actual. 


\subsection{Tema fuertemente debatido}

Las causas históricas ${ }^{1}$ que llevaron a Jesús a la cruz — sin resolver este problema no podemos saber quiénes fueron los responsables de su muertesiguen siendo hoy muy debatidas. S. Légasse habla incluso de que "tiende a implantarse el pesimismo entre los que abordan la cuestion del proceso de Jesús"2. Y H. Conzelmann y A. Lindemann, al presentar los resultados de los análisis histórica-críticos sobre las tradiciones de la pasión de Jesús que han llegado hasta nosotros, sacan la siguiente conclusión: "Históricamente no se puede garantizar mucho más que el hecho de la condena y crucifixión de Jesús'3. Según ellos 4 , cuando se analizan los actores y las causas históricas de la condena de Jesús, sólo hay un consenso fundamental entre los historiadores sobre el hecho de que "una persona sospechosa desde el punto de visla político fue ajusticiada en Jerusalén por los romanos con la cooperación de ciertos grupos judíos". A este consenso podemos añadir también que ello ocurrió siendo Poncio Pilato el procurador de Judea (con toda probabilidad en la pascua del año 30).

Pero no todos los especialistas comparten hoy este pesimismos. Por ello, W. Bösen se atreve a afirmar que "un nuevo optimismo está ganando terreno"6.

En este artículo quisiera recordar cuáles son las causas que han provocado esta situación e informar sobre el estado actual de la investigación? sobre los responsables históricos de la muerte de Jesús.

1. Mi arlículo, que responde a una ponencia realizada en Zamora, España, en septiembre de 1996, en el encuentro anual de los biblistas españoles, no se plantea la cuestión de quitn tuvo la culpa "moral" de la muerte de Jesús, sino que pretende investigar las causas históricas, los motivos concrelos que provocaron su muerte, sin hacer juicios sobre los posibles "culpables". Cfr. J. Becker, Jesus von Nazareth, Berlín, 1996, p. 400.

2. El proceso de Jesús. La Historia, Bilbao, 1995, p. 13.

3. Arbeitsbuch zum Neuen Testament, Tübingen, 1975, p. 378.

4. Ibid. 379. Cfr. también H. Ritt, “'Wer war schuld am Tod Jesu?'. Zeitgeschichle, Recht und theologische Deutung", Biblische Zeitschrift 31 (1987) p. 168.

5. Cfr. P. Stuhlmacher, "Zur Predigt am Karfieilag", en C. Breytenbach-H. Paulsen (eds.), Anfänge der Christologie, Göttingen, 1991, p. 451.

6. Der letzte Tag won Jesus von Nazaret. Was Wirklich geschah, Freiburg, 1994, p. 68.

7. La bibliografia sobre el tema es inmensa. Pero hay que reconocer que, sobre el, desde que apareció en espaniol el artículo de R. Aguirre, "Los poderes del Sanedrin y notas de crítica histórica sobre la muerte de Jesús", Estudios de Deusto 30 (1982) pp. 241-270, no se han hecho grandes progresos. Esto vale también para la obra de S. Legasse, El proceso de Jesús. La Historia (Bilbao, 1995), que recoge bien lo que 


\section{Causas del debate historico}

Fundamentalmente quisiera destacar tres. En primer lugar, la escasez de fuentes, de algún modo históricas, sobre el tema. En segundo lugar, el hecho de que las fuentes principales, los evangelios, están condicionadas por la perspectiva religiosa desde la cual releen e interpretan los acontecimientos. De hecho, los especialistas siguen sin coincidir en sus juicios sobre el posible valor histórico de los relatos. Y, en tercer lugar, los intereses confesionales (iprejuicios?), sobre todo judíos y cristianos, que llevan a los respectivos investigadores a inclinarse por una relectura u otra de los textos, sobre todo en relación con la cuestión, desde Auschwitz mucho más inquietante, de la participación de los judios en la condena y muerte de Jesús, por cuanto ha dado pie, desgraciadamente, a tendencias antisemitas (antijudías) entre los cristianos ${ }^{8}$.

\subsection{La escasez de fuentes}

Aparte de las fuentes especificamente cristianas -fundamentalmente los evangelios, pues son pocos los datos que, al margen de ellos encontramos en el Nuevo Testamento o en los primeros escritos cristianos no canónicos-, sorprende la escasez de noticias sobre el proceso y la muerte de Jesús que encontramos en los autores no cristianos, tanto judíos, como paganos, de la

se puede decir hoy, con una cierla probabilidad histórica, sobre el tema que nos ocupa. Lo mismo puede decirse de tres aportaciones, que Aguirre no pudo consultar, y que se planlean ampliamente esta cuestión. Me refiero a $O$. Betz, "Probleme des Prozesses Jesu", Aufstieg und Niedergang der Römischen Welt II/25 1 (1982) pp. 565-647; W. Reinbold, "Der älteste Bericht uber den Tod Jesu" (Berlín, 1994), quien dedica unas cien páginas al análisis histórico de los textos y K. Kertelge (ed.), Der Prozess Jesu (Freiburg, 1988). A estas obras hay que añadir, entre las más antiguas, las que se consideran más importantes desde el punto de vista de la cuestion historica: P. Winter, On the Trial of Jesus (Berlín, 1961); J. Blinzler, Der Prozess Jesu, Regensburg 41969; D. R. Calchpole, The Trial of Jesus. A Study in the Gospels and Jewish Historiography from 1770 to the Present Day (Leiden, 1971); A. Strobel, Die Stunde der Wahrheit. Untersuchungen zum Strafiverfahren gegen Jesus (Tübingen 1980).

8. Así lo señala H. Ritt, op. cit., pp. 166s ( $f f r$ también la bibliografía que se indica en la n. 8). Por otro lado, habrá que ver, en caso de que respondamos afirmativamente, qué grupos judios participaron realmente, pues, como es obvio, no se puede hablar del pueblo judio en su totalidad. La afirmación que encontramos en Mi 27, 25 de que "todo el pueblo" (Labs es aquí una palabra técnica) clam6: "caiga su sangre sobre nosotros y sobre nuestros hijos", es una interpretación meramente teológica, propia de Mateo. 
Epoca. De hecho las noticias que hallamos en el resto del Nuevo Testamento apenas son relevantes. Son fundamentalmente dos:

a) 1Timoteo 6, 13, un texto que fue escrito por un discípulo de Pablo, bastantes años después de la muerte de Jesús, menciona sólo el "solemne testimonio" ante el tribunal de Poncio Pilato9, sin indicar las causas del mismo ni mencionar si hubo alguna participación de los judíos. En todo caso, no aporta nada nuevo que no se encuentre en los evangelios.

b) En cuanto a 1Tesalonicenses 2, 14-16, un texto probablemente de Pablo, aunque varios autores discuten su autenticidad 10 , se limita a atribuir a los judlos el que "dieron muerte al Señor Jesús" para explicar el hecho de que la comunidad sea perseguida por los paganos, como los cristianos de Judea lo fueron por los judíos ( $f$ fr. también 1Corintios 2, 6.8, donde, según Légassell, los arcontes o "príncipes de este mundo", causantes de la muerte de Cristo, serían, probablemente, las autoridades judías 12 ).

En la literatura judia antigua son pocas las noticias que encontramos sobre la muerte de Jesús y sus causas. Y no resulta fácil datar exactamente la época en que se originaron. La más interesante la encontramos en el Talmud (b. Sanedrín, 43a).

La víspera de la pascua se colgó a Jesús [Yeshâ] el Nazareno. El heraldo había marchado durante cuarenta días delante de él diciendo: "He aquí a Jesús el Nazareno que va a ser lapidado, porque ha practicado la brujería y ha seducido y extraviado a Israel. Que todos los que conozcan algo en su descargo vengan a pleitear por él". Mas no se encontró a nadie para tomar su defensa, y fue colgado la víspera de la pascua.

Como nota Légasse13, "aunque algunos autores se inclinan a ver aquí una tradición propiamente judía, no despreciable desde el punto de vista históricol4, el conjunto se presenta más bien como una relectura de ecos procedentes del proceso y de la ejecución de Jesús y percibidos al entrar en contacto con los cristianos. El proceso, prematuramente desarrollado según los evangelios, es

9. Como nota Légasse, op. cis., p. 25, n. 29, "la fómula epi Pontiou Pilatou tiene sentido judicial, como las que leemos en Mc 13, 9; Mt 28, 14; Hch 23, 30; 24, 20; 1 Cor 6,1 , y en otros lugares, en griego no escrituristico: ver W. Bauer, Wörterbuch, col. 579-580".

10. Cfr. Légasse, op. cit., p. 25, n. 30.

11. Op. cir., p. 25.

12. Los apocrifos cristianos, como las Actas de Pilalo, no parecen aportar nada nuevo ni fidedigno sobre el tema: $c f r$. Légasse, p. 26.

13. Op. cit., pp. 22-23.

14. Nota $18 \mathrm{del}$ autor: "En este sentido, ver D. R. Catchpole, Trial, pp. 4-9". 
presentado aqui bajo una luz mejor. La acusación de brujería da la vuelta a la tradición de los milagros, formulando de nuevo calumnias ya referidas en los evangelios (Mt 12, 24-27 y par.). El "extravío" de Israel, inspirado sin duda en Deuteronomio 13,2-12, describe la experiencia de un movimiento herético, emanado de su seno. Jesús, amenazado de lapidación, castigo judío, fue, sin embargo, colgado (...). Nada figura en ella que permitiera decir que transmite una tradición independiente con respecto a los evangelios y a la versión cristiana de los hechos".

Por otro lado, puede ser útil aprovechar las aportaciones de los estudios sobre el derecho romano y judío de la época para conocer mejor cómo debió ser el proceso de Jesús, y la mayoría de autores han intentado sacar provecho de ello para dilucidar, sobre todo, si pueden ser históricas o no las noticias que encontramos en los evangelios sobre la comparecencia de Jesús ante el Sanedrín y si Jesús pudo ser juzgado y condenado a muerte por él1s.

Notablemenle escasas son también las noticias que encontramos en los historiadores romanos antiguos. Por descontado, "no poseemos documento alguno procedente de los archivos imperiales sobre el proceso de Jesús y nada prueba, a pesar de los alegatos de ciertos padres de la Iglesia, que se hayan conservado en Roma"16. En todo caso, el testimonio más antiguo es el del historiador judío Flavio Josefo, quien en sus Antigüedades judias XVIII, 63-64, lerminadas en Roma hacia el año 93-94, escribe:

En este tiempo vivía Jesús, hombre prudente, si, a pesar de todo, hay que llamarle hombre. Realizaba, en efecto, cosas maravillosas, enseñaba a los hombres que reciban la verdad con alegría y arrasiró tras sí a muchos judios y a muchos helenos. Ese era el Cristo. Y cuando, a denuncia de los principales de nuestra nación, lo condenó Pilato a la cruz, los que le habian amado al principio le conservaron su afecto; se les aparecio, en efecto, el

15. Por ejemplo K. Müller, "Möglichkeit und Vollzug jüdischer Kapilalgerichtbarkeil im Prozess gegen Jesus von Nazareth", en K. Kertelge, Der Prozess, 41-83. De lodos modos conviene tener presente el peligro que apunta Legasse, op. cir., p. 15: "Una segunda trampa es aumentar la aportación del derecho, judio o romano, en el conocimiento de este proceso. Es cierto que en este punto resulta indispensable beber en las mejores fuentes, y eso es lo que nos hemos esforzado en hacer. Mas no hasta el punto de caer esclavos de una perspectiva que bastara para explicarlo todo".

16. Légasse, op. cit., p. 17 (entre los padres cita a Justino, Apol. I, 35, 9; 48, 3; Tertuliano, Apol. 21, 24; 5, 2; Eusebio, Hist. ecl. 11, 1, 1-3, y añade: “Ninguno de estos escrilores tenía ante sus ojos el menor documento de cancilleria y Eusebio parece depender claramente aqui sólo de Tertuliano"). 
tercer dia, vivo de nuevo, como lo habian anunciado los divinos profetas, asi como orras mil maravillas relativas a él. Hasta el día de hoy sigue subsistiendo la raza de los cristianos, asf́ llamados a causa de él.

Aunque algunos siguen cuestionándolo, hoy se acepta en lo fundamental este testimonio como original y fidedigno (a excepción de los fragmentos en cursiva que son interpolación cristiana), pues Josefo muestra en otros lugares de su obra que conocía el movimiento cristiano17. Aparte de la afimmación de que Jesús fue crucificado por Poncio Pilato, el testimonio resulta interesante por cuanto afima que lo hizo por "indicación" o por "denuncia" de los "principales" de la nación judía18.

Poco posterior (hacia el año 100) es el testimonio de Tácito en sus Anales $\mathrm{XV}, 44$, a propósito de la persecución que sufrieron los cristianos en Roma, cuando Nerón intentó descargar en ellos la culpabilidad del incendio de la ciudad. Según Tácito, "el fundador (auctor) de esta denominación, Christus, habia sido sometido a suplicio por el procurador Poncio Pilato bajo el principado de Tiberio". Como nota Légasse19, el texto citado "parece haber sido insertado y depender de algún retoque, pero todos los autores ven en él la mano de Tácito. (...) De todos modos además, aparte de la datación expresa de la muerte de Jesús bajo Tiberio, Tácito no añade nada al testimonio de Josefo. Incluso retrocede respecto a éste, puesto que omite toda participación de los judíos en este asunto, cuya causa, por consiguiente, no nos proporciona"20.

17. Cfr. R. E. Brown, The Death of the Messiah, New York (2 vol.) p. 377; Légasse, op. cit., pp. 18s. Los fragmentos en cursiva son vistos por la mayoría de autores como interpolación cristiana.

18. Légasse, op. cil., p. 19, n. 7 , observa que “la palabra endeixis es vaga. La encontramos aún dos veces más en Josefo en $A J$, XIII, 306, con el sentido neutro de "indicación", e ibid., XIX, 133, con el sentido de "denuncia". E. Nodet ("Jésus et Jéan-Baptiste selon Josèphe", Revue Biblique, 92, 1985, p. 334) piensa que, en el Testimonium Flavianum, la ambigūedad es intencional y que Josefo ha querido evitar la palabra kategoria, "acusación" (ver AJ, XVIII, 81. 139. 179. 250), lo que reducirfa un tanto la participación de los sumos sacerdotes en el asunto. Pero el matiz es mínimo".

19. Op. cit., p. 20.

20. El documento de Mará bar Serapion, un estoico sirio, resulta difícil de datar y, en todo caso, no parece gozar de una información que no sea la cristiana, cfr. Légasse, op. cit., pp. 20-21. 


\subsection{La "parcialidad" de los relatos evangelicos}

Hoy nadie cuestiona este punto. Los evangelios no pertenecen ciertamente al género literario histórico, tal como lo entendemos nosotros a partir de los historiadores del siglo pasado. Están escritos prioritaria y conscientemente desde una perspectiva religiosa por unas personas creyentes, que quieren ayudar a los lectores a descubrir la dimensión religiosa21 de unos acontecimientos que son fundamentales para el origen y desarrollo de las iglesias cristianas. Por ello, hoy se está de acuerdo en que no se pueden leer como si se tratara de un vídeo de los acontecimientos o de informes judiciales de lo que ocurrió entonces.

Entre las tendencias, fácilmente detectables, que dificultan la "objetividad" histórica de los evangelios, se encuentra, en primer lugar, su tendencia, por razones apologéticas -no resultaba nada recomendable pertenecer a una religion que tenía su origen en un ajusticiado por los romanos por razones políticas-, a disimular la participación de los romanos en la muerte de Jesús, cargando la responsabilidad más bien en los judíos. Por ello, cuanto más recientes son los evangelios, más se responsabiliza a los judíos y menos a los romanos. En segundo lugar, podemos detectar también, con facilidad, la tendencia a responsabilizar cada vez más a los fariseos de la oposición a Jesús y, por tanto, tambien de su muerte, pues éstos eran los adversarios reales de las comunidades cristianas en la época en que se escriben los evangelios. Con todo -y ello resulta sorprendente en este contexto-, en los relatos de la pasión es donde la oposición de los fariseos menos aparece.

Pero en la actualidad, en contra de la tendencia bien representada por Bultmann, se señala también, a mi juicio con razón, que es injusto considerar que están desprovistos de interés y material que podamos considerar como histórico22. El interés que manifiesta Lucas, al inicio de su obra (cfr. Le 1, 1-4), por mostrar que se ha preocupado por investigar la realidad de lo ocurrido en la vida y muerte de Jesús, que él narra, ciertamente, desde una perspectiva pascual, pero no simplemente "imaginativa", resulta un aspecto fundamental de su obra, que también se encuentra en los otros evangelistas. Pues ante el hecho de que han ido muriendo los testigos directos de la vida de Jesús, ya Marcos expresa la preocupación por recuperar su vida concreta -por enraizar las tradiciones crislianas posipascuales en la historia- a fin de evitar que Jesús se convierta en un mero mito desdibujado y sin raíces históricas.

21 Cfr. X. León-Dufour, art. "Passion (Récits de la)", Dicrionnaire de la Bible Supplement VI, 1960, col. 1429; Légasse, op. cir., p. 27.

22. Légasse, op. cit., p. 15, denomina con razón una "trampa" "relegar los relatos evangélicos de la pasión al exclusivo dominio de la leyenda piadosa sin consistencia histórica". 
Lo dicho no excluye, sino todo lo contrario, que intentemos hacemos una idea, lo más "objetiva" y científica posible, de la fiabilidad de las fuentes evangélicas de que disponemos para intentar descubrir cuáles fueron las causas históricas reales que llevaron a Jesús a la cruz. Para ello se han ido perfilando cada vez mejor los criterios que permiten un acercamiento a la realidad histórica que subyace a los relatos 23 .

Para clarificar en qué medida podemos utilizar los evangelios para descubrir las causas históricas de la muerle de Jesús, la primera cuestión que se nos plantea aquí es la de la relación de los evangelios entre sí. La mayoría de autores cree hoy, a mi juicio con razón, que el más antiguo de los evangelios es el de Marcos y que tanto Mateo como Lucas tuvieron delante el relato de Marcos y lo utilizaron para sus relatos de la pasión y muerte de Jesús. Pero aparte de Marcos, ¿dispusieron también de otras fuentes? No todos los especialistas coinciden en la respuesta a este problema.

Personalmente, pienso que Mateo no utilizó otras fuentes para la composición de su relato de la pasión, donde se ve claramente que sigue a Marcos24. Los pocos textos propios no responden a fuentes propias originales de la pasión, sino a su teología.

Más difícil resulta responder la pregunta con relación a Lucas25. Pero después de comparar Lucas con Marcos, Légasse concluye: "no estamos obligados a otorgar privilegio al relato de la pasión; también aquí ha podido usar Lucas a Marcos tan libremente como lo hace en el resto de su evangelio"26.

23. En el campo católico puede consultarse, por ejemplo, la obra, editada por K. Kertelge, Rilclfrage nach Jesus. Zur Methadik und Bedeutung der Frage nach dem historischen Jesus, Freiburg, 1974.

24. Asf Legasse, op. cif., p. 28. Un análisis detallado del proceso contra Jesús en Mateo puede encontrarse en 1 . Broer, "Der Prozess gegen Jesus nach Matthāus", en Kertelge, Prozess, Pp. 84-110.

25. Asf lo sefiala Legasse, op. cir., p. 29, quien remile, para informarse sobre las distintas opiniones, a J. Emst, Das Evangelium nach Lukas, Regensburg, 1977, pp. 643-644; J. A. Fitzmyer, El evangelio según Lucas, Madrid, 1986, vol. I, pp. 147-150; F. J. Matera, Passion Narratives and Gospel Theologies: Interprefing the Scriptures through Their Passion Stories, New York-Mahwah, 1986, pp. 152-155 y 238-239. Tambien puede verse con provecho G. Schneider, "Das Verfahren gegen Jesus in der Sicht des dritten Evangeliums (Lk 22, 54 - 23, 25). Redaktionskritik und historische Rúckfrage", en Kertelge, Prozess, pp. 111-130.

26. Op. cir., p. 29. Es lo que opina también W. Radl al estudiar las tradiciones propias de Lucas en Le 22, 67s; 32, 2 y 23, 6-12 (cfr. "Sonderüberlieferungen bei Lukas? Tradilionsgeschichtliche Fragen 20 Lk 22, 67 f; 23, 2 und 23, 6-12", en Kertelge, Prozess, Pp. 131-147) y G. Schneider, Das Verfahren, ibid, Pp. 111-130. Pero no 
En cuanto a Juan, la cuestión es aún más compleja, pues nos ofrece un relato profundamente teológico de los acontecimientos y los especialistas no acaban de ponerse de acuerdo sobre las relaciones entre el evangelio de Juan y el de Marcos. Después de estudiar la cuestión, Légasse27 concluye "de manera provisional, aunque con una buena dosis de probabilidad:

- es prácticamente imposible establecer la existencia de una fuente continua en la base del relato joánico de la pasión;

- a menos que admitamos que el único empleo posible de un evangelio anterior sea aquel del que testimonian Mateo y Lucas, no se puede descartar la idea de que Juan ha conocido los sinópticos y ha sido influenciado por ellos;

— Juan ha recogido tradiciones independientes de estos últimos;

- Juan manifiesta, en el relato de la pasión, la misma personalidad independiente que en el resto de su evangelio y la parte de su redacción en él es considerable, tanto en la relación de los hechos como en las palabras"28.

En cuanto a Marcos, el texto más antiguo (escrito hacia el año 70), hay coincidencia fundamental entre los especialistas en que utiliza un relato anterior de la pasión que recoge tradiciones más antiguas. Se discute la amplitud de este relato. Pero no su existencia. Este relato, aunque esté marcado por intereses teológicos, debe su existencia también al interés por los acontecimientos reales de la pasión29. Marcos mismo parece haber sido respetuoso con sus fuentes.

Por tanto, será sobre todo con la ayuda de Marcos, y en parte también de Juan, como intentaremos acercamos a la realidad histórica de la muerte de Jesús.

\section{Las perspectivas confesionales}

Como señala con acierto Légasse30, "las preocupaciones confesionales, judías y cristianas, interfieren a menudo en este campo y perjudican la libertad de la investigación, bien a causa de una voluntad apologética de reducir la parte

todos los aulores estarían de acuerdo con este juicio. Hoy por hoy, el debate sobre este punto sigue abierto.

27. Op. cit., pp. 29-31.

28. Op. cir., p. 31.

29. Cfr. J. Roloff, Das Kerygma und der irdische Jesus. Historische Motive in den Jesus-Erzählungen der Evangelien, Göttingen, 1970, p. 51. Sobre lodo, R. Pesch, Das Markusevangeliun, Freiburg, 1984, vol. 2, pp. 23-24, cfr. 1ss, insiste, a mi juicio con exceso, en la fidelidad del relato premarcano a lo ocurrido históricamente. Más matizado es el juicio de Reinbold, op. cit., p. 225.

30. Op. cit, p. 13. 
de los judíos en este asunto, o bien por no atreverse a aplicar a los relatos evangélicos las reglas estrictas de la crítica literaria e histórica".

Dos obras muestran ejemplarmente esta dificultad. La del judío P. Winter, El proceso a Jesús 31 , defiende la siguiente tesis, que Légasse 32 resume así: "admitido que el sanedrín tenía entonces poder para ejecutar a los condenados, si Jesús hubiera sido juzgado y condenado por el tribunal judío, hubiera debido ser lapidado. Ahora bien, sufrió la crucifixión, una pena romana. Luego no fueron los judíos quienes lo condenaron, sino los romanos. Fueron eslos últimos quienes organizaron y llevaron adelante todo el proceso, sirviéndose de los jerarcas saduceos, y quienes ejecutaron a Jesús como agitador político".

Pero hay que advertir, en relación con la tesis de Winter, que esta obra, más que de un análisis lo más objetivo posible de los textos de que disponemos, brota más bien del deseo de liberar a los judíos de la responsabilidad en la muerte de Jesús, cosa comprensible, dadas las consecuencias que esta acusación ha tenido al fomentar determinadas actitudes antisemitas 33 .

En el extremo opuesto se encuentra el exegeta católico J. Blinzler, $E l$ proceso de Jesús ${ }^{34}$, quien sostiene la tesis, difícilmente compatible con los resultados de los numerosos análisis de los textos evangélicos que se han realizado con ayuda de los métodos histórico-críticos, de que los textos evangélicos sobre el proceso de Jesús pueden ser considerados como sustancialmente históricos y que no hay incompatibilidades, dignas de mención desde el punto de vista histórico, entre los distintos relatos ${ }^{35}$. Al final de su

31 La primera edicion On the Trial of Jesús apareció en Berlín, en 1961, con el título On the Trial of Jesus (Studia Judaica) y la segunda, editada por A. Burkill y G. Vermes, en 1974. Ver también sus artículos "Marginal Notes on the Trial of Jesus", Zeitschrifi für die Neutestamentiliche Wissenschaft 50 (1959) pp. 14-33 y 221-251; "Markus 14, 53b.55-64. Ein Gebilde des Evangelisten", Zeitschrift für die neutestamentliche Wissenschaft 53 (1962) pp. 260-263; "Zum Prozess Jesu", en W. P. Eckert (ed), Antijudaismus in Neuen Testament, Munich, 1967, pp. 95-104. Por lo general $-\mathrm{y}$ a diferencia de to que ha ocurrido con Blinzler-, sus tesis no han encontrado muchas resonancias (contra ello protesta Rejnbold, op. cit., 222).

32. Op. cir., p. 13.

33. AsI también Légasse, op. cir., p. 14. el cual afimma: "Jesús fue claramente detenido a iniciativa y por orden de las autoridades judías, y diferido por ellas después a la justicia de Pilato".

34. Barcelona 1960 (no contiene los excursos y los añadidos de las ediciones $3^{\mathbf{l}}$ y $\mathbf{4}^{\mathbf{l}}$ ). El original, Der Prozess Jesu, fue publicado en Regensburg, en 1951. La $4^{\circ}$ edición, corregida, es de 1969.

35. Con ello Blinzler no quiere afirmar que los textos no estén configurados por la fe, como reconoce, op. cit., p. 71. Sólo quiere subrayar que contienen noticias que 
investigación llega a la misma conclusión que los primeros predicadores cristianos: la responsabilidad principal recae sobre los judíos 36 .

Esto supuesto, vamos ahora, dando un paso más, a intentar clarificar el aspecto más complicado de mi investigación: la participación de los judíos en la muerte de Jesús. Habrá que ver qué personajes judíos, en qué medida y por qué razones participaron en la condena a muerte de Jesús.

\section{Participación de los fudios en la muerte de Jesús}

\section{1. ¿Quiénes fueron los responsables del prendimiento de Jesús?}

La primera cuestión que se nos plantea es si y en qué medida los judíos participaron en el prendimiento y condena a muerte de Jesús. Como hemos visto, algunos lo cuestionan ${ }^{37}$. Pero el hecho de que el comando que describe Marcos 14, 43 fuera armado con espadas y palos y fuera enviado por "los sumos sacerdotes, los escribas y los ancianos" (Mc 14, 33), muestra que, al menos para Marcos (cfr. también 8, 31; 14, 53; 15, 1), los enviados realizaban una operación querida, de algún modo, por miembros del sanedrín, sin participación de los romanos 38 . Pero no se trata necesariamente de una intervención de todos los

tienen valor histórico. Lo mismo vale para los otros evangelistas. Según él, ibid., pp. 68-69, el que Juan subraye más los rasgos mayestáticos de Jesús no significa que los haya inventado. El esceptieismo de muchos autores frente a la historicidad de lo relatado por Juan brotaría de la época en que se creía, equivocadamente, que Juan habría sido escrito hacia la mitad o al final del siglo II.

36. Op. cit., p. 447 (de la $4^{\circ}$ ed.). Y añade en la p. 448 que, según los evangelios, tres son las causas por las cuales los miembros del sanedrín se opusieron a jesús: 1) veian peligrar su autoridad delante del pueblo; 2) temian, sobre todo la parte saducea del sanedrín, que si el movimiento de Jesús seguía creciendo, ello provocaría una intervención de los romanos, lo cual comportaria la pérdida de los pocos derechos que les quedaban a los judios; 3) Jesús resultaba odioso, sobre todo a los fariseos, por su predicación religiosa. Los motivos de la condena serían, pues: ansias egoistas de poder político, nacionales y religiosas.

37. Por ejemplo P. Lapide, Wer war Schuld an Jesu Tod?, Gütersloh, 1987, pp. 5354.120; fr. también W. Fricke, "Standrechtlich geloreuzigr", Buchschlag, 21987, p. 56 (citado por Bösen, op. cit, p. 374).

38. Cfr. Ritt, op. cit., p. 170; Reinbold, op. cit., pp. 240 y 249; Bosen op. cit. p. 149. Para R. Schnackenburg, El evangelio según san Juan, Barcelona, 1980, vol III, p. 273, la participación de los romanos en el prendimiento está, desde el punto de vista histórico, prácticamente excluida. La mención de la cohorte romana en Juan 18, 3.12 responde a una intención teologica y es dificilmente compatible con lo que 
grupos del sanedrín, como parece suponer Marcos desde una relectura actualizada del acontecimiento. En todo caso, como nota Légasse39, "dado que el sumo sacerdote o los sumos sacerdotes son siempre mencionados, y en ocasiones sólo ellos, en la preparación y el desarrollo de esła empresa asesina, se les puede otorgar en este caso más peso que a los otros partidos judios e inscribirlos entre los datos heredados de la tradición". En cuanto a los fariseos, no mencionados por Marcos, pero sí por Juan 18, 3, "son un añadido sin valor histórico"40. En todo caso, Marcos parece reflejar bien la historia cuando afirma que fue un grupo meramente judío -y fundamentalmente saduceo- el responsable del arresto de Jesús ${ }^{41}$. Volveré más tarde sobre este punto.

\section{2 . Causas que provocaron la oposición judía contra Jesús}

Una vez hemos comprobado el hecho de la participación judía en el arresto de Jesús, hemos de preguntamos, en segundo lugar, por qué ocurrió todo ello.

Los evangelios ven la pasión y muerte de Jesús como una consecuencia del modo como vivió y de la pretensión de autoridad con que se presentó. Y nada serio, desde el punto de mira histórico, obliga a pensar que no fue así.

El debate aparece entre los especialistas cuando quieren concretar, con más exactitud, las razones que motivaron la oposición de los jefes judíos y quiénes fueron los que realmente se opusieron a él y provocaron su muerte. Pero si los

ocurrió realmente. Como nota Légasse, op. cir., 38, "resulta difícil de creer que unos soldados romanos, bajo la autoridad presente de su jefe, conduzcan a Jesús a casa del sumo sacerdote, que es lo que, según el testimonio unánime de los evangelios, tuvo Jugar. Por otra parte, Pilato, durante el proceso, parece ignorar todo lo relativo a esła intervención, y los que le llevan a Jesús no son más que judios según todos los testimonios". A ello se une que los sinóplicos ignoran esta intervención romana. El texto de Juan no respondería a un hecho histórico, sino a su interpretación teologica. En cambio, según S. Ben-Chorin, Bruder Jesus. Der Nazarener in jüdischer Sicht, Munich, 71984, p. 153, un grupo de legionarios, bajo las órdenes de un oficjal romano, participó en el prendimiento, dando así legitimidad a la acción. Pero no da razones convincentes en favor de su tesis.

39. Op. cit., p. 37; cfr. también Reinbold, op. cit., p. 208.

40. Légasse, op. cit., p. 37; véase también Ritt, op. cit., pp. 168s y Reinbold, op. cit., p. 308, quien sostiene que los fariseos "no tuvieron nada que ver con la muerte de Jesús". Pero aunque no llevaran la voz cantante en la delención de Jesús, pienso que no se puede excluir sin más su participación, como reconoce el mismo Légasse, op. cit., pp. 67s, cuando analiza la participación de los fariseos en la muerte de Jesús.

41. Así Légasse, op. cit., p. 47; véase también Ritt, op. cir., p. 171; Betz, op. cí., p. 394. Becker, Jesus, p. 401, Jo considera "la mejor suposicion". 
motores del arresto y de la condenación fueron judíos, habrá que buscar, como motivo, aquellos aspectos de la actuación de Jesús que, en el mundo judio, podían provocar una tensión tan fuerte con otro(s) grupo(s), de modo que bastara para que lo acusaran ante Pilato. Con todo, conviene tener presente que los motivos por los cuales le acusaron ante Pilato no necesitan ser los mismos que provocaron realmente el deseo de acabar con él42.

Parece un hecho innegable que Jesús se encontró relativamente pronto en su vida pública con la oposición, más o menos encamizada, de determinados grupos representativos de su pueblo, aunque fue en Jerusalén donde se agudizó y culminó este proceso que lo llevó a la cruz 43 .

No resulta fácil situar en qué momento de su vida pública empezó esta oposición a Jesús, pues es Marcos (seguido luego por los otros evangelistas), quien, por motivos cristológicos, la sitúa ya al comienzo de su vida pública (cfr. Mc 3, 6: un texto ciertamente redaccional, pero no necesariamente deformador de lo que debió ocurrir históricamente), mostrando, luego, cómo esta oposición va creciendo. A la vez, Marcos sitúa también en la vida pública de Jesús una serie de textos en los cuales Jesús prevé, de algún modo, su muerte en Jenusalén (cfr. Mc 8, 31; 9, 31; 10, 32-34) e indica el carácter salvífico de la misma (Mc10, 45)44. Estos textos, en su formulación actual, están sin duda coloreados, por lo menos en parte, por la experiencia pascual45. Pero ello no implica que sean una mera creación postpascual. Pues sólo si pensamos que Jesús no encontró una oposición seria durante su vida pública podemos sostener que Jesús no contó con la posibilidad de una muerte violenta46. Y aunque no resulta fácil comprobar la autenticidad

42. Así Becker, Jesus, p. 401.

43. Como nola Becker, Jesus, p. 402, puede que un acontecimiento en Jerusalén fuera la ocasión del prendimiento, por ejemplo la acción de Jesús contra el Templo o una palabra crítica contra él como la que encontramos en Marcos 13, 2par y 14, 58par, pero entonces sería sólo un último impulso, que culminaría una oposición, que llevaba gestándose desde hacia tiempo.

44. Se discute en qué medida alguna de las predicciones de Jesús, que Marcos sitúa en Galilea y en la subida a Jerusalén, son ipsissima verba Jesu. Pero parece histórico que Jesús contó con su muerte violenta y que preparó a sus discípulos para ella. Sobre la posibilidad de que Jesús diera un significado salvífico a su muerte violenta, cfr. lo que dice Becker, op. cit., pp. 417-421 (a propósito de Mc 10, 45 y 14, 22-25).

45. Contra Reinbold, op. cit., p. 294, quien sostiene que son sólo vaticinia ex eventu.

46. Lo ocurrido en El Salvador con Mons. Romero resulta iluminador en este sentido. Sus tres años de testimonio evangélico y compromiso en favor, sobre todo, de las mayorías empobrecidas y masacradas de su pueblo, le granjeo la oposición creciente de las oligarquías políticas, económicas y, en buena parte también, religiosas. Por ello, pudo preveer su fin trágico y anunciar "si me matan, resucitaré en el pueblo salvadoreño". 
histórica de cada una de las palabras de Jesús en su formulación actual, sin embargo, el conjunto de ellas, sobre todo si se tiene en cuenta su estilo sorprendente de vida y otros textos, que hablan de la oposición de su familia y conciudadanos (cfr. Mc 3, 21.31-35 y 6, 1-6a), así como la de otros grupos religiosos de su época, pernite afirmar que Jesús tuvo que contar con la posibilidad y, luego, probabilidad, de un final violento. Las palabras de juicio de Jesús contra sus adversarios, que encontramos, por ejemplo, sustancialmente, en la parábola de los pérfidos viñadores (cfr. Mc 12, 1-12par), hay que considerarlas como propias de Jesús y siluarlas en su vida pública (y no necesariamente sólo cuando subió a Jerusalén). Ellas muestran que Jesús experimento una creciente y dura oposición por parte de grupos significativos de sus conciudadanos 47 y tuvo que contar con la posibilidad de una muerte violenta. Esto explicaría el que celebrara una cena de despedida con sus discípulos que, sin ser probablemente pascual, expresaría que "la dinámica del reinado de Dios no quedaba afectada por su destino y que él mismo participaría en la comida salvífica definitiva" 48 .

¿Cúales son, pues, los motivos concretos por los cuales Jesús podría haber sido entregado a la muerte por instigación de determinados grupos judíos? Los evangelios mencionan tres, pero los especialistas no acaban de ponerse de acuerdo sobre la base histórica que subyace a la interpretación, fundamentalmente teológica, de los evangelistas; así como hay también un debate sobre la participación real de los distintos grupos. Empezaremos por resolver la primera cuestión, pues de ella dependerá que saquemos unas conclusiones u otras sobre los responsables de la muerte de Jesús (o por lo menos sobre la parte de responsabilidad judía en ella).

\subsection{Posibles motivos de la oposición a Jesús}

\subsection{La oposición y crítica de Jesús al Templo de Jerusalén}

Dos son las acciones que parecen implicarlo. Por un lado, la escena de la "purificación del Templo". Y, por otro, una palabra de Jesús anunciando su destrucción.

47. Así también Becker, op. cir., pp. 414s, quien señala que también sus discípulos tuvieron que contar con esta posibilidad, pues, de lo contrario, no se explicaría la traición de Judas. $C$ fr. también lo que Becker dice, op. cit, pp. $415 \mathrm{~s}$, sobre Lucas 13, 32, un texto que parece de Jesús.

48. Becker, op. cil., p. 425. 


\subsubsection{La escena de la purifícación del Templo}

La encontramos en Marcos 11 ,15-18par; Juan 2, 14-16. El marco de la escena, concretamente el hecho de que esté situada por Marcos en el contexto de la pasión, así como el v. 18, que relaciona el gesto de Jesús con su muerte, han sido creados por Marcos49. Si ello es asl, no tendríamos ninguna indicación que obligara a unir, históricamente, el gesto simbólico con la decisión de los sumos sacerdotes de hacer morir a Jesús. Pero tampoco podemos excluirlo sin más. Y me parece más probable que fue así.

Por olro lado, la escena, en lo fundamental histórica50 y con un profundo significado simbólico, no debí́ ser muy llamativa, pues tuvo que realizarse en el patio de los paganos, donde se encontraban los vendedores y cambistas. El patio era muy grande y estaría lleno de peregrinos y de mercaderes. Por ello, la acción de Jesús - nada hace pensar en una colaboración armada de sus discípulos51- pudo realizarse, como máximo, en un ámbito pequeño, pues de lo contrario hubiera provocado inmediatamente una intervención de los romanos que, durante las fiestas, vigilaban constantemente el Templo y la ciudad para evitar, a tiempo, posibles disturbios, que hubieran podido resultar peligrosos políticamente.

La cuestión que se nos plantea, entonces, es cuál pudo ser el alcance que Jesús le atribuý y cómo debieron comprenderlo los que la vieron o fueron informados de ella. Según Légasse52, "se supone que acompañó su gesto con algunos comentarios a la usanza de los antiguos profetas. Los que los evangelistas ponen en sus labios en este momento tienen pocas posibilidades de remontarse hasta él, pues de las dos citas antitéticas de Isaías 56,7 y de Jeremías 7,11 , una reproduce prácticamente al pie de la letra el texto griego de los Setenta y la otra se apoya en él. El conjunto procede de una pluma cristiana, que condena con ferocidad el negocio practicado en los accesos al santuario y que anuncia, a modo de castigo, su supresión en aras de un culto universal".

De todos modos, hay que observar críticamente, contra Légasse, que el hecho de que las citas estén sacadas de los Setenta no implica, necesariamente,

49. Así Becker, op. cit., pp. 407 y 423 . Juan, quizás por motivos teológicos, la sitúa al comienzo de la vida pública.

50. Como nota Legasse, op. cir., p. 52, "sea el que sea el momento de la vida de Jesús donde haya que situar el acontecimiento, su historicidad fundamental está garantizada. Como carece de precedente y de modelo bíblico, presenta los rasgos de lo inédito y, como tal, no ha podido ser inventado". Cfr. también Reinbold, op. cit., pp. 288-290.

51. Cfr. Légasse, op. cit., p. 53.

52. Op. cit., pp. 53s. 
que Jesús no hubiera podido utilizar estas citas, naturalmente en la versión conocida por él, pues estaba familiarizado con el Antiguo Testamento y nada exige -más bien afirmaría lo contrario- que tuviera menos capacidad teológica creadora que el relato premarcano de la pasión. La actitud más bien crítica de Jesús frente al Templo me parece innegable y se encuentra reflejado en todos los evangelios, que jamás presentan a Jesús realizando un sacrificio o acto de culto en el Templo. Sólo lo utiliza como ámbito de su enseñanza. Con su acción y con su palabra, Jesús simbolizaría, por adelantado, la destrucción del Templo. Pues, como nota Légasse53, "el mercado del Templo, lejos de parecerse al comercio de objetos piadosos que hay en tomo a nuestros santuarios, era una necesidad para el ejercicio del culto", pues sin él ni podía pagarse el impuesto ni podían procurarse los animales para el sacrificio. En este sentido, atacar el mercado era atacar el culto mismost. Y atacar el Templo tenía unas enormes consecuencias polílicas, por cuanto, en la visión de los jefes saduceos, ponía en peligro la seguridad misma del Estado judío, dependiente de los romanosss. Así lo interpreta Marcos, quien subraya -y no veo por qué no hay que suponer que no refleja bien lo que debió ocurrir históricamente- que cuando "los sumos sacerdotes y los maestros de la Ley se enteraron" de lo que Jesús había hecho, buscaban la manera de acabar con él (cfr. Mc 11,18).

La mayoría de los especialistas, sin embargo, interpreta la acción de Jesús de otra manera: no como una puesta en cuestión del culto en el Templo, sino, más bien, como una purificación del mismo o una amplificación de la pureza y santidad del Templo a otros ámbitos. En este caso, "esta 'purificación' se uniría a otros ajustes de la religión efectuados por Jesús en vistas a un retomo a la auténtica voluntad de Dios"56. Pero si fuera así, ello no tenía, entonces, por qué

53. Op. cit., p. 56.

54. Así Légasse, op. cit., p. 57, quien añade: "Es preciso añadir que Jesús, a diferencia de las críticas mencionadas más arriba, no ha pronunciado nunca una palabra de censura dirigida a los sacerdotes en el ejercicio de su función, lo que invita a pensar que apuntaba a algo más que a la práctica concreta del culto. En cuanto al gesto mismo, el hecho de 'volcar' (katestrephein) las mesas y los puestos (Mc 11, 15par.), sobre todo si nos inspirarnos en el lenguaje bíblico, resulta apto para evocar la destrucción, mientras que otros gestos, como la efusión de agua, expresan mejor la idea de purificación".

55. Así D. Dormeyer, "Die Passion Jesu als Ergebnis seines Konflikts mit führenden Kreisen des Judentums", en H. Goldstein (ed.), Gottesverächter und Menschenfeinde? Juden zwischen Jesus und frìhchristlicher Kirche, Düsseldorf, 1979, p. 231. Cfr. también F. Mussner, Die Kraft der Wurzel. Judentum -Jesus- Kirche, Freiburg, 1987, pp. 127s. Para Reinbold, op. cit., pp. 312s ésta sería la hipótesis más "verosímil" a partir de los texios.

56. Así Légasse, op. cis., p. 55, quien, aunque no comparte esta opinión, cita a Marcos 2,$27 ; 3,4 ; 7,1-23 ; 10,1-12 ; 12,18-27.28-34$ par.; Mateo 5, 20.48; 23, 16-26par. 
provocar el que decidieran matarlo. A ello hay que añadir, como nola Becker57, que una acción así resultaría sorprendente en Jesús, quien ni parece haber valorado las normas exteriores de pureza cúltica, ni parece haber actuado con violencia física contra personas y cosas. Por ello no me parece ésta la interpretación más adecuada del gesto de Jesús.

Podemos concluir, pues, que si bien no es probable que fuera la acción de Jesús en el Templo la que provocara, por sí sola, el que lo mataran, sí debió contribuir a que arrestaran a Jesús, sobre todo si fue ilustrada con alguna de sus palabras radicales, anunciando la destrucción del Templo. Fue, probablemente, la gota de agua que colmó la medida.

\subsubsection{El anuncio de la destrucción del Templo}

Lo encontramos en diversas versiones, que podemos agrupar en dos bloques: Marcos 14, 58par; 15, 29par; Juan 2, 19; cfr. Hechos 6, 14 y Marcos 13, 12par58. Pero, ¿cuál o cuáles de ellas podemos considerar como auténticas? Los especialistas no se ponen de acuerdo y no resulta fácil dirimir la cuestión.

Marcos 14, 58b59, "yo derribaré este templo hecho por manos humanas y en tres días construiré otro no hecho por manos humanas", no coincide en la formulación con Juan 2, 19 ("destruyan este templo y, en tres días, yo lo levantaré de nuevo"). Ambos textos muestran señales claras de reelaboración teológica y los especialistas divergen sobre cuál de ellos se acerca más a una posible palabra original de Jesús, que hubiera podido provocar una oposición que le causara la muerte.

Según Becker60, la formulación marcana es, tanto por su forma como por su

Y para clarificarla, ańade, ibid, pp. 55s, una serie de cilas de la Biblia $(\mathrm{Mal} 3,3)$ y del judaísmo antiguo (SalSal 8, 8-13; 1QpH 12, 8), que reflejan una actitud crítica con respecto al ejercicio del culto en el Templo.

57. Op. cit., pp. 409 s.

58. Según Bösen, op. cir., p. 178 (cfr. lambién los autores citados por él en la p. 380, nn. 113 y 114), tiene todos los indicios, en su núcleo más original, de ser un logion autético, pues no puede derivarse ni de las tradiciones judlas ni del cristianismo primitivo. Y el hecho de que aparezca en diversas formas muestra que su interpretación creaba dificultades a las primeras comunidades. Un estudio de estos textos puede encontrarse en J. Schlosser, "La Parole de Jésus sur le fin du Temple", New Testament Studies, 36 (1990) pp. 398-414.

59. Los textos paralelos no son más originales que Marcos, y Marcos 15, 29 alude a este texto; Hechos 6, 14 depende de él.

60. Cfr. op. cit., pp. 403s. También Bösen, op. cit., p. 179, sostiene que la formulación que más se acerca a lo que dijo Jesús la encontramos en Juan 2, 19. 
lenguaje, secundaria, sobre todo en lo que se refiere a la contraposición "hecho por manos humanas" "no hecho por manos humanas", que sería un añadido judeocristiano helenista (en esto último coinciden todos los autores). Según él, también el hecho de que se ponga la destrucción en primera persona, como si Jesús fuera a realizar la destrucción, es secundario y Marcos lo pone como calumnia de los adversarios, que él intenta corregir a partir de Marcos 13, 2. En cuanto a la indicación "en tres días", que en los evangelistas implica una alusión a la pascua (Juan lo explicita aún más en 2, 21-22), no tiene por qué ser leída cristológicamente y el mismo Juan presupone una interpretación inicial que se refería al Templo. Por ello, Becker sostiene que el texto más original es el de Juan: “es, además, un imperativo irónico típico, como los que, por lo demás, encontramos en la profecía (Am 4, 4; Is 8, 9s). Lo podemos parafrasear así: 'Cumplan tan sólo la condición de destruir este Templo, que yo entonces cumpliré mi palabra y lo reedificaré!"'. No es, piensa Becker en contra de lo que defienden muchos, que Juan sea una suavización de Marcos 14, 58, un texto peligroso cúltica y políticamente para los cristianos, sino que los cristianos aceptan como tradición propia la que encontramos en Marcos 13, 2 y Juan 2, 19, que reflejan mejor la tradición más original. Son los adversarios los que atribuyen, calumniosamente, la afimación de Marcos 14, 58 a Jesús. De hecho, 1Hen 90, 29s y 11QT 29, 8-10 muestran que en el judaísmo de la época existía la espera de una destrucción del Templo y de su reconstrucción, al fin de los tiempos. Por ello piensa Becker que, supuesto que el texto más original no habla de que Jesús mismo destruirfa el Templo, el simple anuncio de su destrucción y reconstrucción no pudo ser el motivo que lo llevó a la muerte. Por otro lado, según Beckerbi, no parece que ni siquiera este texto sea original de Jesús, pues no puede ser casual que, en su predicación del reino de Dios, haya dejado de lado la tradición de la alianza y de Sión, por lo que no parece que Jesús hubiera unido la realización de la salvación, para la que emplea la imagen de la comida escatológica, con el motivo de la reconstrucción escatológica del Templo. A ello se añade que para Jesús, la plenitud del reino es obra propia de Dios.

Según Légasse, en cambio, Juan 2, 19 es claramente secundario62. En cuanto a Marcos 14, 58, si prescindimos de la precision posterior "hecho-no hecho por manos de hombre", "el resto se revela exento de retoque perceptible. Que sea una creación cristiana ex eventu forma parte de lo inverosímil. En efecto, suponiendo que estas palabras nacieran sobre las ruinas del Templo, poco después del año 70 , ridiculizaban a Jesús, puesto que el Templo no había sido destruido por Jesús, sino por los romanos. Añadamos que en el relato del proceso se han querido neutralizar estas mismas palabras por medio del

61. Op. cit., p. 405.

62. Op. cis., p. 61. 
desacuerdo entre los testigos, señal de que se las consideraba embarazosas, aunque, en la misma medida, inscritas en la tradición en el tema de las causas de la condenación de Jesús" 63.

De todos modos, no resulta fácil saber exactamente qué pudo formular Jesús ( $y$ más si lo hizo en más de una ocasión). Pero "es preciso admitir, como mínimo, que Jesús anunció la ruina y la reconstrucción del Templo, y que se atribuyó un papel en este doble movimiento. ¿Cuál? Dado el estado en que se encuentra la documentación que poseemos, es imposible dar una respuesta segura a esta cuestión. A lo sumo podemos sugerir que, dada la misión que se atribuía frente al próximo reinado de Dios, se veía colocando, por medio de su predicación, las premisas de una renovación total del culto, cosa que pudo expresar con algunas fórmulas incisivas, cuyo tenor habría sido extremado por el "falso testimonio" del proceso"64. Si esto fue así, como me parece más probable, se comprende que la actitud de Jesús provocara la ira tanto de los "sumos sacerdotes", como de la población de Jerusalén, que vivía, en parte, del Templo65, y la de muchos de los peregrinos que subían a Jerusalén para la pascua. En todo caso, debió ser una de las causas reales de su arresto y ulterior condena a muerte. Pues "Jesús con sus críticas al Templo y a su culto, y rodeado de discípulos a los que inculcaba sus puntos de vista sobre el futuro, comenzaba a sembrar el desorden en el seno de la población, y esto, en plena peregrinación pascual"66, se convertía en una amenaza para el orden público, que justificaba el que fuera perseguido por las autoridades judías saduceas ${ }^{67}$ y crucificado por los romanos.

En cuanto a la formulación de Marcos 13, 2b, "No quedará aquí piedra sobre piedra, todo será destruido", tiene, según Becker68, todas las apariencias de ser una profecía ex eventu, pues así quedó el Templo, según Josefo (bell VI, 250266; VII, 1-3). Y otras profecías de juicio que encontramos en labios de Jesús no son tan concretas. Por lo tanto, no sería original de Jesús, ni influiría en su condena. Pero aun en el caso de que fuera original, no sería motivo suficiente $\rightarrow$ piensa Becker - para que condenaran a muerte a Jesús, pues profecías de este tipo las encontramos a menudo en la tradición profética (cfr. 1R 9, 7-8; Jer 7,

63. Op. cit., pp. 62s. También se discute la fecha exacta en que fue escrito Marcos.

64. Op. cit., p. 63.

65. Cfr. G. Theissen, "Lo profecla de Jesús sobre el Templo. Profecía y tensión entre el campo y la ciudad", en su obra Estudios de sociología del crisrionismo primitivo, Salamanca, 1979, pp. 79-101 (condensado en Selecciones de Teologia 17 (1978) pp. 330-338.

66. Legasse, op. cit, pp. $66 \mathrm{~s}$.

67. Así Rith, op. cit, p. 171.

68. Así Becker, op. cit., pp. 405s, que cita a Walter, Tempelzerstörung, $41 \mathrm{~s}$. 
14; 26, 6.9.18; Mi 3, 12; y también TLev 15, 1; 1Hen 90, 28; Tg Neof Lv 26, 19). Y, por otro lado, el intento por condenar a muerte a Jesús hijo de Anás por anunciar la destrucción de Jerusalén y del Templo fracasó, pues los romanos se contentaron con azotarlo y lo liberaron.

Pero aquí Becker no tiene suficientemente en cuenta que los judíos intentaron que los romanos mataran a Jesús hijo de Anás y que los romanos lo liberaron porque, a diferencia de Jesús de Nazaret, no lo vieron como políticamente peligroso, sino como un loco que, además, no tenía discípulos. Por otro lado, la argumentación de Becker no es convincente en este punto, pues el ejemplo del profeta Jeremías (cfr. Jer $7,1-15 ; 26,1-15 ; 38,1-5$ ) muestra lo peligroso que podía ser anunciar, en contra de la tendencia general, la destrucción del Templo y de Jerusalén. Y en la época de Jesús, la oposición religiosa provocó a menudo reacciones violentas 69 .

Tampoco convence cuando saca la conclusión 70 de que no se puede mantener con fundamento que Jesús se opusiera al Templo de Jerusalén, ya que, si hubiera anunciado la destrucción del Templo y el juicio contra Jerusalén, entonces no se entendería cómo la comunidad posipascual se instaló, al inicio, en Jerusalén y no se constituyó en Galilea. Becker no tiene suficientemente en cuenta aquí que los primeros compañeros de Jesús necesitaron tiempo para comprender el alcance profundo de muchas palabras de Jesús y que fueron, quizás, los denominados "helenistas" quienes comprendieron mejor la intención de Jesús y las consecuencias hondas de algunas de sus palabras más radicales en relación con la religión judía. Y, como nota Légasse, la desaparición del Templo y de su culto concuerda bien con el horizonte escatológico de Jesús y su predicación del reino en la cual no parece que haya lugar para el culto sacrificial, aunque es verdad (y en ello concuerda con Becker) que Marcos 13, 2 no parece un texto original de Jesús en su formulación actual71.

En todo caso, dado el significado del Templo, como centro del poder religioso, político y económico, la crílica de Jesús al Templo fue, como mínimo, uno de los puntos importantes que influyó en que las autoridades judías impulsaran su crucifixión que sería también bien vista por diversos grupos de la

69. Brown recoge varios ejemplos de ello -enire ellos el martirio de Santiago- en Death, pp. 393-395.

70. Op. cit., p. 410.

71. Op. cit., p. 60. Pero Légasse reconoce, ibid., que se puede dudar de la autenticidad de esta palabra, sobre todo si se la compara con la formulación de Marcos 14,58 , de contenido análogo, pero cuya interpretación presenta muchas más dificultades. Según él, el texto tiene "más bien el aspecto de refundición facililante inspirada en el Antiguo Testamento" y, por tanto, no es este texto el que provocó la muerte de Jesús. 
ciudad de Jerusalén, que se beneficiaba del Templo72. Si a ello se une que a los saduceos ya les tenía que molestar, tanto su predicación del reino de Dios, con sus acentos escatológicos, como su solidarizarse con los pobres, denunciando el egoísmo de los ricos, y su relación inicial con el movimiento de Juan Bautista, se comprende mejor que intentaran acabar con él73.

\subsection{El estilo de vida de Jesús que implicaba una crítica a la Ley y a la identidad religiosa jodía}

La conducta de Jesús y su modo de hablar, ya en Galilea, provocó sin duda escándalo entre muchos de sus conciudadanos (Becker 74 habla de "la impresión de conjunto" que Jesús debía producir), aunque ello fuera por diversos motivos. Los especialistas tienen razón cuando afirman que la oposición con el grupo fariseo se acentuó después de Yabnia. Pero ya antes tuvo que darse, pues, de lo contrario, resultaría difícil de explicar el martirio de Esteban (y las persecuciones contra las primeras comunidades cristianas de que habla continuamente Hechos) y la oposición y persecución, entre otros, del fariseo Pablo (cfr. 1Co 15, 9; Ga 1, 13; Fip 3, 6) contra los primeros seguidores de Jesús75. Si no se tiene esto suficientemente en cuenta "se devalúa" - como nota acertadamente Aguirte76 - "la novedad de Jesús que se afirmó también como ruptura y libertad respecto a las tradiciones de los padres y a la misma letra del Antiguo Testamento; y se pierde el escándalo que suscitó a los ojos de muchos hombres sinceramente religiosos de su tiempo y que radicaba, de alguna manera, en la transcendecia vislumbrada de su persona por su actitud con la ley religiosa, que para ellos resultaba blasfema. Jesús muere en nombre del Dios del Antiguo Testamenlo, no por una simple confusión ni por un conflicto sin relación directa con lo teológico, sino por afirmar "otro' Dios y otra relación con ell".

72. Así Bösen, op. cî., pp. 180s. Cfr. también en el mismo sentido J. Maier, "Beobachtungen zum Konflikıpotenlial in neutestamenllichen Aussagen úber den Tempel", en Broer, op. cit., pp. 173-213, sobre todo 177s y 187-191.

73. Asl Ritt, op. cif., pp. 171s, quien hace notar también, como otros autores, que el origen galileo de Jesús -Galilea era la patria de numerosos movimientos revolucionarios no resultaba precisamente una carta de recomendación para las autoridades saduceas de Jenusalén a las que interesaba no tener conflictos con los romanos y aprovecharse del storus quo.

74. Op. cit., p. $\mathbf{4 1 0 .}$

75. Asl Becker, op. cit., pp. 411 y 426. Sin duda, la interpretación postpascual del crucificado acentuaría la oposición de los fariseos al movimiento cristiano. Pero no creo que empezara sólo con dicha predicación. Es lo que subraya con razón Aguirre, op. cit., p. 265.

76. Op. cit., pp. 265 s. 
Sobre todo, algunos rasgos de Jesús, por ejemplo sus comidas con los publicanos y pecadores, que pertenecen, sin duda, a su vida real de Nazaret, y su cuestionamiento de las "leyes de pureza (cúltica)", que daban identidad al pueblo de Israel, en particular después del exilio ( $c f r$. Mc 7,15), tenían que molestar al grupo fariseo, especialmente preocupado por fomentar la "santidad", la "separación" del pueblo de lsrael de los otros pueblos y de los pecadores77. Provocar el que "justos" y "pecadores" compartieran la mesa era cuestionar un "principio religioso" sacrosanto y "tradicional" en Israel. Para colmo, estos signos iban unidos a su anuncio de la venida del reino de Dios, como don gratuito de la bondad del Padre, sobre todo a los pecadores y marginados. También su anuncio del juicio sobre Israel y su crítica a la concepción de la historia de la salvación que predominaba, con distintos matices, en los grupos judíos, debía resultar particularmente molesta, por cuanto parecía implicar la puesta en cuestión de la tradición de Sión y una cierta cesura en la historia de Israel78.

Por último, su pretensión personal de autoridad y poder, y el modo como la ejercitaba tenían que resultar particularmente escandalosas79. Sobre todo cuando se atrevía a reinterpretar, basándose simplemente en su autoridad, la ley de Dios, llegando a no guardar el sábado (cfr. Mc 2, 23 - 3, 6; Jn 5, 1-9) o cuestionando, sin ser siquiera "rabino" o "sacerdote", normas y principios importantes de "pureza religiosa" (cfr. Mc 7,1-5.14-15).

77. Sobre la aclitud de principio que Jesús tomó frente a la ley judía puede verse la postura más matizada - frente a las opiniones contrapuestas de Käsemann y Sanders- que toma J. W. Taeger analizando Marcos 7, 15 (en el contexto de 7,123), un texto del Jesús histórico que muestra que la postura de Jesús tenía que resultar poco tolerable para el judaismo de su época (cfr. "Der grundsāztliche oder ungrundsåtzliche Unterschied. Anmerkungen zur gegenwärtigen Debatte um das Gesetzesverständnis Jesu`, en I. Broer (ed.), Jesus und das jüdische Gesetz, Stuttgart, 1992, pp. 13-35.

78. Así Becker, op. cir., p. 410.

79 En este punto insiste Mussner en un capílulo de su libro Die Krafi der Wurzel, que lleva por título "La pretensión de Jesús", pp. 104-124. Cfr. también Becker, op. cir., pp. 411 s. En cambio Légasse es de olro parecer. Según él, op. cir., p. 66, "nada hay en los relatos del proceso de Jesús que nos permita sospechar que sus lomas de posición sobre la ley y sus preceptos hayan jugado el menor papel en su arresto y su muerte. Pero existe una razón suplementaria y, sin duda, la más importante, para excluir un motivo de este lipo del 'expediente' de Jesús. Y es que ni la jerarquía ni el sanedrín por ella presidido trataban semejantes cuestiones". En este caso, "hubiera debido comparecer ante un tribunal rabínico, un bet din presidido por legistas" (ibid). Pero, en contra de Légasse conviene tener en cuenta que esto solo será válido si Jesús sólo hubiera resultado conflictivo por cuestiones de interpretación de la ley. Pero no fue así. 
Algunos de los elementos recogidos aquí podrían dar pie, desde la perspectiva del movimiento celota — sin duda posterior a él-, a una interpretación de Jesús de tono político-revolucionario, popular desde Eisler. Pienso, por ejemplo, en su crítica de la riqueza o en la formación de un grupo de discípulos que tenian un sistema normativo propio, en el cual se relativizaban los vínculos familiares en función del reino de Dios y se daba una entrega absoluta al maestro basta estar dispuestos al martirio80. Pero como hace notar Dautzenberg81, en contra de dicha interpretación hablan, entre otras cosas, la procedencia de Jesús del grupo en tomo a Juan Bautista, su apertura a los pecadores y publicanos (colaboradores con el imperio), su exigencia de amar a los enemigos, así como su renuncia a la violencia y a un mesianismo político.

\subsubsection{La pretensión de Jesús de ser el Mesías, el hijo de Dios}

El interrogatorio ante el sanedrín que nos presenta Marcos menciona como motivo de la acusación contra Jesús el que éste hubiera anunciado la destrucción del Templo (Mc 14, 58), indicando (cfr. 14, 59) que el testimonio era falso por no ser coincidente. Pero esta precisión parece una añadido del último redactor, sin el cual la acusación sería precisa y abrumadora82. En el texto actual, el motivo decisivo de la condenación de Jesús es el hecho de que éste se confesara como Mesías e Hijo del hombre que vendría a juzgar a sus propios jueces ( $c f$. Mc 14, 61-64). Pero aparte de que aquí aparece un texto claramente configurado por la fe posipascual83, y que Jesús difícilmente se daría, sin más, a sí mismo los títulos cristológicos que aparecen en el textoB4, no parece que éste fuera un motivo suficiente para que las autoridades judías desearan la condenación a muerte de Jesús. De hecho, cuando Rabí Aquiba proclamó como Mesías a Bar Kochbá no fue condenado a muerte por ello8s. De todos modos, si no la

80. Así Dautzenberg, Prozess, p. 151.

81. Ibid.

82. Así Légasse, op. cit., pp. 70s.

83. Por esto, Légasse que analiza el texio, op. cit., pp. 72s, saca la conclusión de que "es aún toda la escena la que depende de una mano cristiana. Y es que este 'proceso' es, en realidad, una especie de compendium cristológico entregado a la reflexión creyente del lector" (ibid, 73). Y añade ibid.: "De esle relato, de hecho, queda poco cuyo origen pueda figurar entre las realidades históricas. Unicamente la amenaza de destruir el Templo tiene sus raíces en las palabras de Jesús. $C f r$. también Dautzenberg, Prozess, p. 151.

84. Así, por ejemplo, lo subraya Reinbold, op. cit., 243 (cfr. también p. 249), para quien la pregunta del sumo sacerdote de si Jesús era el mesías y la respuesta positiva de Jesús le resulta "históricamente impensable".

85. Becker, Jesus, p. 402. 
pretensión mesiánica ${ }^{86}$, por lo menos la pretensión de autoridad con que se presentó Jesús (como el profeta "definitivo" con el que empezaba a hacerse presente el reinado de Dios de modo incondicional) sí debía provocar la oposición de varios grupos judíos, entre ellos los escribas, tanto si eran fariseos como si no87.

\section{4. ¿Hubo una condena formal del sanedrín?}

En este momento conviene que nos preguntemos, puesto que es una cuestión muy debatida hoy, si hubo una sesión formal del sanedrín y una condena a muerte de Jesús en ella.

De hecho, lo que ocurrió entre el prendimiento y la entrega de Jesús a Pilato es una de las cuestiones más debatidas en el campo de la investigación. Pues los mismos textos evangélicos dan pie a ello al mostrar diferencias notables, sobre todo entre Marcos-Mateo, Lucas y Juan.

El análisis histórico-crítico de los textos no acaba de resolver la cuestión. El texto más antiguo parece ser el de Marcos 14, 53-72; 15, 1 . Contiene cinco escenas: 1) 14, 53.55-64: primer interrogatorio (¿proceso?88) ante las autoridades judías (¿el sanedrín?). 2) 14, 65: burla y maltrato de Jesús. 3) 14, 54.66-72: negaciones de Pedro. 4) 15, 1a: segundo interrogatorio y decisión

86. Por otro lado, dada la ambigüedad del término, Jesús no se debió presentar como "Mesfas" en su vida lerrena, sino que fue confesado así por los crislianos y cristianas después de pascua. Pero sl pudo dar la impresión a algunos de sus seguidores y adversarios de que se consideraba como tal.

87. Así lo interpreta Mussner, Krafi, p. 129 (cfr. pp. 120-131), haciendo notar -para ello cita a G. Lohfink, Der Letzte Tag Jesu. Die Ereignisse der Passion, Freiburg, 51985, p. 38- que Jesús, además de responder positivamente a la pregunta del sumo sacerdote de si era "el Mesías, el hijo del Bendito", añade algo que le presenta con una pretensión que supera ampliamente la pretensión mesiánica: "y verán al Hijo del hombre sentado a la derecha del todopoderoso venir entre las nubes del cielo" (Mc 14, 62). En todo caso, no parece que se pueda tomar como causa de la condena de Jesús una entrada triunfal en Jerusalén como la que describe Marcos 11, 7-10. Pues parece dificil que ello no hubiera implicado una intervención inmediata de los romanos, ya que, como nota Legasse, "es dudoso que los romanos hubieran dejado desarrollarse ante ellos y, por asi decislo, ante sus propios ojos, una manifestación de esta envergadura, dirigida, según todas las apariencias, contra ellos mismos" (op. cit., p. 51; cfr. también p. 52).

88. Cfr. G. Schneider, Die Passion Jesu nach den drei älisesten Evangelien, Munich, 1973, pp. 55-82; E. Linnemann, Studien zur Passionsgeschichte, Göttingen, 1970, pp. 127-135; O. Betz, "Probleme des Prozesses Jesu", en W. Haase (ed.), Aufstieg und Niedergang der römischen Welt Il/25,1 (1984) pp. 614-640. 
(¿del sanedrín?) de entregar a Jesús a Pilato; 5) 15,1b: entrega de Jesús a Pilato.

Pero no resulta fácil saber lo que realmente ocurrió, al margen de la interpretación leológica de los textos, aunque el relato contiene sin duda un núcleo histórico. Mateo sigue a Marcos, con pequeños detalles (por ejemplo la mención de Caifás), que no son significativos para nuestra cuestión. En todo caso, en Marcos y Mateo los dos interrogatorios, uno durante la noche y otro de madrugada, parecen tener carácter de "proceso". En cambio, Lucas habla sólo de un interrogatorio por la mañana y, a diferencia de Marcos y Mateo, que hablan de que todo el sanedrín, presidido por el sumo sacerdote, condena a Jesús, menciona sólo de paso al sanedrín (Lc 22, 66). Y mientras en Marcos y Mateo la acusación se centra en una crítica de Jesús contra el Templo y en la confesión mesiánica, en Lucas está en cuestión que Jesús se confiesa "hijo de Dios" (Lc 22, 70). Mientras en Marcos y Mateo, el sanedrín condena a muerte a Jesús, en Lucas se indica sólo que lo conducen a Pilato $(\operatorname{Lc} 23,1)$.

En cuanto a Juan, se aparla notablemente de los sinópticos, ya que, según él, Jesús es conducido ante todo a Anás e interrogado por él, en lo cual Juan parece haber conservado un recuerdo tradicional, aunque formulado según su teología (cfr. Jn 18, 14.19-2389). Luego es conducido a Caifás (Jn 18, 24) y entregado, sin que se tome ninguna decisión oficial, a Pilato $(\mathrm{Jn} 18,28)$. A diferencia de lo que ocurre con Lucas, la mayoría de autores cree que Juan dispone de una fuente propia, distinta de Marcos90, que retoca ampliamente según sus intereses teológicos. Juan sitúa en 11, 45-53 el propósito del sanedrín de matar a Jesús. La afirmación de Caifás "más vale que muera un hombre por el pueblo que no que todo el pueblo perezca" (Jn 11, 50) concuerda bien con el hecho de que consiguió mantener su puesto de sumo sacerdote unos diecinueve años (del 18 al 37) y debí́ llevarse bien con Pilato, pues lo perdió cuando Pilato fue depuesto91. Y ante Pilato (cfr. 18, 28 $19,16 a)$, serán los judios los motores de la condena a muerte de Jesús. La reunión en casa de Anás correspondería a lo que Marcos presenta como una sesión del sanedrín —que no parece que tuviera lugar-durante la noche92.

89. Asf Légasse, op. cir., pp. 72-77, quien nota, ibid., p. 76, que "no es extraño (...) que se condujera a Jesús ante Anás, pues este último continuaba ejerciendo entonces un poder moral sobre el conjunto de la hierocracia".

90. Bösen, op. cit., p. 158, que cita Schnackenburg, op. cit, vol. IIl, pp. 288-296 (en la edición española) y J. Blank, El evangelio segin san Juan, Barcelona, 1984, vol. 4/3, pp. 44-54 (de la ed. española). Pero Légase, op. cit., p. 73, que reconoce este hecho, constata que "esta versión no debe suscitar falsas esperanzas, porque es menos original de lo que cabría esperar".

91. Cfr. Légasse, op. cir., p. 74.

92. Como nota LÉgasse, op. cit., pp. 79s., "los laboriosos esfuerzos de los eruditos, encaminados a suprimir la incompatibilidad entre los datos arqueologicos y los de 
La cuestión, entonces, que queda pendiente es si hubo o no una sesión del sanedrín por la mañana, como parece suponer Marcos 15, 1, y si en ella se condenó formalmente a Jesús. Por otra parte, y en orden a ver cuál pudo ser la participación de las autoridades judías en la muerte de Jesús, hay que clarificar también la cuestión de si el sanedrín gozaba o no de la potestad para condenar a muerte a alguien.

Por la mañana hubo ciertamente una sesión, distinta de la de la noche93, que correspondería a la noticia de Juan de que Anás envió a Jesús, atado, a Caifás (Jn 18, 24), desde donde fue conducido, luego, al palacio del gobemador (Jn 18, 28). No parece que el sanedrín en su conjunto se reuniera por la mañana para condenar a Jesús 94 . Se trataría, más bien, de un grupo reducido, una especie de consistorio, formado por una docena de sacerdotes y laicos, ricos y bien considerados en Jerusalén (Josefo en Anr. XVII 9,3 los llama "los diez primeros" y en Bell.II 1, 3; 20, 7 "los arcontes"), que ayudaban al sumo sacerdote en las funciones normales de gobiemo y eran su grupo de consulta95.

En cuanto a la cuestión controvertida de si los judíos disponían o no de la

los evangelios, no lienen ya razón de ser a partir del momento en que se sustrae a la historia la sesión noctuma del sanedrín y se admite que no se trata, en realidad, más que de una presentación de Jesús a Anás, en su propio domicilio. La misma respuesta podemos dar a los que recuerdan que, según la Mishná, los procesos en materia criminal no debían ser debatidos más que de día".

93. Así Légasse, op. cit. Pp. 77s, quien, citando a P. Benoil hace notar que la palabra symboulion no significa nunca una "decisión" o "resolución" (con la que habría terminado la sesión noctuma), sino “un 'consejo', es decir, una asamblea deliberativa considerada o bien en cuanto miembro constituido, o bien en su mismo acto de deliberación".

94. Así también Légasse, op. cit., pp. 84s, quien hace notar que de este modo se evita la objeción de que, según la Mishná, estaba prohibido realizar juicios en víspera de sábado o de un día de fiesta grande.

95. Cfr. Bōsen, op. cit., pp. 167s, que cita, B. Reicke, Die neutestamentliche Zeirgeschichre. Die biblische Welt 500 v.- 100 n. Chr., Berlin, 21968, p. 110. Bösen, ibid., p. 169 añade que Anás, a quien Juan (cfr. 18, 13.19.22.24) implica más claramente que los sin6pticos en los acontecimientos, representa a este pequerio grupo. $Y$ aunque su nombre haya podido ser añadido posteriomente, el era la eminencia gris en el palacio sacerdotal y estuvo implicado en la detención de Jesús. En este sentido no es importante si llevaron a Jesús primero a Anás o a Caifás. Ya H. Cousin, Las tertos evangélicos de la pasión, Estella, 1981, p. 221 ( $f$ r. pp. 221-228) sacaba la conclusión: “No hubo ningún proceso judio, ninguna condenación a muerte decretada juridicamente por la autoridades religiosas judias". 
posibilidad para condenar a muerte a alguien96, Légasse, después de estudiar el tema, llega a la conclusión siguiente: "En realidad, no sólo el sanedrín carecía de autorización para hacer ejecutar una sentencia de muerte, sino que ni siquera la que hubiera podido emitir tenía valor a los ojos del poder romano"97, tal

96. Cfr. J. Jeremias, "Zur Geschichulichkeit des Verhörs vor dem Hohen Rat", en Id., Abba. Studien zw neutestamentlichen Theologie und Zeitgeschichte, Göttingen, 1966, pp. 139-144; E. Lohse, Die Geschichte des Leidens und Sterbens Jesu Christi, Gūtersloh, 1964, pp. 77ss; K. Mūller, "Moglichkeit und Vollzug jüdischer Kapitalgerichtsbarkeit im Prozess gegen Jesus von Nazareth", en Kertelge, Prozess, pp. 41-83; J. Gnilka, "Der Prozess nach den Berichten des Markus und Matthäus mit einer Rekonstruktion des historischen Verlaufs", en Kertelge, ibid., Pp. 2B-31. Sobre el estado actual de la cuestión, cfr. G. Otte, "Neues zum Prozess gegen Jesus? Die 'Schuldfrage' vor dem Hintergund der christlich-jüdischen Beziehungen", Neue Juristische Wocherschrift, 16, (1992) pp. 1019-1026 (citado por Bösen, op. cir., p. 378 n. 76).

Son sobre todo autores judios los que defienden que sí disponía el sanedrín de la posibilidad de condenar a muerte (y ejecular) a Jesús, pues ello implicaría que, si lo condenó Pilato, los judíos no habrian participado en la condena y muerte de Jesús: cfr. J. Juster, Les Juifs dans l'Empire Romain. Leur condition juridique, économique ef social, New York, 1914, vol II., pp. 133, n. 1 y p. 142, n. 2; H. Lietzmann, Der Prozess Jesu, Berlín, 1934, pp. 313-322; P. Winler, Trial, pp. 7590 y 109; P. Lapide, Wer war schuld an Jesu Tod?, Gūtersloh, 1987, Pp. 43-66; Fricke, op. cit., pp. 178-190.

97. Op. cit., pp. 93-94 (cfr. pp. 88-92); también Dautzenberg, Prozess, 147; K. Berger, Wer war Jesus Wirklich?, Stuttgart, 1995, p. 183. Cfr. también J. Blank, "Die Johannespassion. Intention und Hintergünde", en Kerleige, Prozess, p. 165; cfr. también Blank, Juan 4/3, p. 46 (de la ed. española); J. Klausner, Jesus von Nazareth. Seine Zeit, sein Leben und seine Lehre, Jenusalem, 1952, p. 478; Barnmel, Judaica. Kleine Schrifien, vol. II, pp. 59-72; Schnsckenburg, Juan, vol. III, p. 287 (de la ed. espanola que lo traduce como un "pre-interrogatorio"); Strobel, op. cif., p. 20 (cfr. pp. 18-45); Gnilka, Prozess Jesu, p. 31; id., Jesus von Nazareth. Botschofi und Geschichte, Freiburg 1990, p. 295; Müller, Möglichteit, Pp. 52-58; Ritt, op. cit., 170 (para éste la única excepción se daría cuando un pagano profanara el Templo; así también Brown, op. cil, p. 371); Betz, op. cit., p. 616. Reinabold, op. cit. p. 258 , n. 111, señala que cada vez crece más el consenso de los especialistas en este punto. Légasse, op. cir., p. 93, se opone a la tesis de Winter (Trial, p. 109) según la cual "antes del aío 70 de la era comín el sanedrín tenía plena jurisdicción sobre los judíos acusados de falta contra la ley religiosa judía y tenfa autoridad para pronunciar y aplicar libremente sentencias de muerte en conformidad con las disposiciones de la legislacion judla". Las opiniones a favor y 
como lo afirma Juan 18,3198 .

Podemos, pues, reconsinuir así los aconlecimientos hasla la entrega de Jesús a Pilato. Por la noche (no hay razones serias para cuestionar las indicaciones de Marcos y Juan), la tropa judía que ha prendido a Jesús, lo conduce directamente a casa de Anás, donde se halla reunido el consistorio o grupo reducido de consejeros que ha planeado el prendimiento, pues fue la aristocracia sacerdotal jerosolimitana la que hizo detener a Jesús y la que lo acusó delante de Pilato. El objelo de la sesión es clarificar y preparar la sesión de la mañana99, en la que se preparará la acusación y se tomará la decisión de entregar a Jesús a las autoridades romanas, a fin de conseguir que se lo condene a muerte100. Aunque resulta difícil datar el texto de Sanh IV 1, no parece plausible históricamente que el sanedrín se reuniera para un proceso por la noche. Como observa J. Becker101, tanto el relato prejoanneo de la pasión, como Marcos, señalan que la tropa lleva a Jesús a los "sumos sacerdotes", que en la tradición de Juan son identificados con Anás, aunque, desde el punto de vista histórico, parecería más obvio que Jesús fuese llevado a Caifás y fuese interrogado por él102. En este caso (Caifás y) Anás estarían acompañados de un grupo reducido de sanedristas (una especie de consejo permanente). Por la mañana, Jesús es llevado al lugar donde el sanedrín se reúne. Allí es interrogado y condenado en un proceso que no se puede juzgar formal (ni estaría el sanedrín al completo ni se cumplen todos los requisitos de un proceso formal: no parece que se realizaran sesiones del sanedrín en sábado y en las grandes festividades, amén del hecho de que no

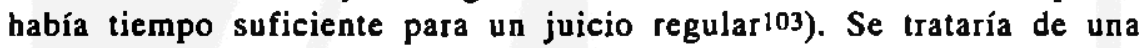

en contra pueden verse en Brown, op. cit., pp. 363-372. También Aguirre, op. cit., p. 265 , sostiene que se puede pensar que los judios sí gozaban de la posibilidad para condenar a muerie. Pero las razones que da no me parecen convincentes.

98. Sobre el valor histórico de este texto, cfr. Strobel, op. cit., pp. 43-45; efr. también Schnackenburg, Juan, vol. [Il, p. 303; Blank, Juan, vol. 4/3, p. 46; Brown, op. cit., p. 371.

99. En cambio, Becker piensa que lo condujeron directamente a casa de Caifás ( $f$ r. op. cit., p. 426). En todo caso, si fue en casa de Anás, no se ve por qué Caifás no tenía que estar presente. Sin la noticia de Juan, pensariamos, más bien, que fue llevado a Caifás.

100. Asl Bōsen, op. cir., pp. 175 y 195; Becker, op. cir., p. 412, habla de que los acusadores tenían que llegar a un consenso interno sobre la causa de la condena y a una formulación externa que luviera posibilidades de éxito ante Pilato.

101. Das Evangelium nach Johannes, Gütersloh-Würzburg, Vol. II, 1981, Pp. $548 s$.

102. Así Bōsen, op. cit., p. 175.

103. Así Bösen, op. cit., pp. 176s y 196; vêase también Reinbold, op. cit., pp. 249-258. Que no habia tiempo suficiente lo indican Ernst, Markas, p. 447 y Gnilka, El 
"anacrisis"104. Lo que ocurrió realmente en estos encuentros noctumos, sólo podemos conjeturarlo. Becker 105 piensa que una hipótesis bastante obvia y que responde a lo que el historiador puede saber sobre lo que provoco la oposición a Jesús, es la siguiente. Según Flavio Josefo (Ant 18, 116-119), Herodes detuvo e hizo asesinar a Juan Bautista, porque temía que este incómodo profeta sedujera con éxito al pueblo. De hecho, según Deuteronomio 13, 1-6; 18, 9-22 hay que matar a los falsos profetas que seducen al pueblo. Esto se podia aplicar a Jesús como juicio global, lo cual tenía una doble ventaja táctica: por un lado, todo grupo judio podía interpretar así lo que le escandalizaba en Jesús y, por el otro, retocado un poco políticamente, podía servir de acusación ante Pilato. Por otro lado, al denunciarlo a Pilato y lograr, así, su condena por razones políticas, "se disimulaban las reivindicaciones religiosas del profeta Jesús, convirtiéndolas en pretensiones de orden político"106, denigrándolo así ante sus posibles seguidores.

\section{5. ¿Quiénes fueron los opositores reales de Jesús?}

Según el relato premarcano de la pasión $-y$ en principio parece responder a la historia-, los motores principales de la muerte de Jesús fueron los "sumos sacerdotes", fundamentalmente pertenecientes al grupo saduceo. Pues son ellos sobre todo los que se sentían profundamente inquietos y cuestionados en su autoridad y modo de "dirigir" al pueblo por la actividad y enseñanza de Jesús. A la vez, tenían miedo que la actividad de Jesús cuestionara el status quo político -y los privilegios - que ellos habían logrado, colaborando con los romanos.

Pero, ¿quiénes formaban el grupo que decidió acusarlo ante Pilato? Dos son las interpretaciones que se han dado. Por un lado, E. Schürer considera a los

evangelio segín san Marcos, Salamanca, 1986, vol II, p. 336. A ello hay que añadir que en tiempo de Pilato, el sanedrín no gozaría de la competencia para poder condenar a muerte a nadie, tal como lo señala Juan 18,31 , un texto que por lo que conocemos de la época no tiene por qué ser puesto en cuestión (así Becker, op. cit., pp. 427s, que cita Strobel, op. cit., pp. 21ss y Müller, Möglichkeit, pp. 66ss).

104. Así Bösen, op. cit., p. 177, que cita Gailka, Marcos II, p. 287; Klausner, Jesus, p. 463; Schneider, Passion, p. 60; Blank, Juan, 4/3, p. 46. Ritt, op. cit., p. 170, dice que esta "instrucción de un expediente" (Voruntersuchung), realizada por miembros significativos del sanedrín, o intertogatorio, concluyó con la decisión formal de acusar a Jesús. Y añade (ibid., pp. 170s) que no se puede decir más sobre el tema porque no podemos anticipar en el tiempo las fuentes del derecho talmúdico (Mishna, Gernara) ni tenemos fuenles del derecho saduceo.

105. Op. cit., pp. 412 s.

106. Cousin, op. cir., p. 225. 
sumos sacerdotes "como una sociedad compuesta por el sumo sacerdote en ejercicio, por sumos sacerdotes depuestos (lo eran frecuentemenle en aquel tiempo) y por miembros de la aristocracia sacerdotal"107. En cambio J. Jeremias piensa que 'formaban un 'colegio' que ejercía la autoridad sobre el culto y el orden exterior del Templo; aunque procedían de familias pontificias, no se identificaban con ellas"106. Por otro lado, también formaban parte del sanedrín "escribas" (grammateis), juristas profesionales, fariseos en su mayoría, y nobles laicos (los "ancianos"), que, junto con los sacerdotes, estaban adheridos especialmente al movimiento saduceo. Si bien es preciso reconocer que la influencia farisea, que era grande sobre la población, tenía posibilidades de repercutir en el sanedrín, sigue siendo cierto que el elemento sacerdotal era el que llevaba las riendas del poder en la línea de la hierocracia postexílica"109. En todo caso, "el sumo sacerdole y los jerarcas que le rodeaban podían emprender, sin hacer intervenir la asamblea del sanedrín, operaciones de policía. En concreto, éstas dependian del "comandante del Templo", primer dignatario después del sumo sacerdote"110. Su decisión debió satisfacer a buena parte del pueblo de Jerusalén, que vivía del Templo y a algunos peregrinos que habían subido para la fiesta.

\section{Participación de los romanos en la muerte de Jesús}

La participación de los romanos en la muerte de Jesús parece incuestionable, desde el punto de vista histórico. Por eso, apenas me detendré en este punto. $Y$ el hecho de que Jesús muriera crucificado -un hecho que no puede ser puesto en duda razonablemente- comporta que tuvo que ser por motivos políticos que Pilato hizo crucificar a Jesús111. Pues la cruz era un castigo que los romanos utilizaron en Palestina, entre el 63 a. C. y el 66 d. C., sólo contra los que se rebelaron contra ellosi12. Y ello vendría confirmado por el hecho, recogido en los evangelios, de que Jesús fue crucificado entre dos lestai (Mc 15, 27 par Mi), una palabra que Josefo, entre otros, utiliza para designar a los rebeldes políticos 113 .

107. Así Legasse, op. cit., p. 48, que cita History, vol. II, pp. 233-236.

108. Légasse, op. cit., p. 48, quien cila Jerusalén en tiempos de Jesús, Madrid, 1977, pp. 167-178. Sin embargo, según Légasse, ibid., "no podemos considerar como históricamente probada la existencia del 'colegio' en cuestión".

109. Légasse, op. cit., p. 49.

110. Legasse, ibid.

111. Así H.-W. Kuhn, art. "Kreuz II", Theologische RealEnzyklopedie, vol. 19 (1990) p. 717; también, entre otros, Rilt, op. cit., pp. 172 s.

112. Cfr. Kuhn, ibid, p. 717.

113. Cfr. Kuhn, ibid. y Aufstieg und Niedergang der Römischen Welt II, 25/1, pp. 726s. 
En todo caso, parece cierto históricamente que Jesús fue juzgado y condenado por Pilato en un juicio regular. El juicio se realizaría por la mañana y es narrado por los cuatro evangelios, aunque, como nota Légasse114, "ninguna de las cuatro versiones puede pasar por una recensión exacta de los hechos". El que Jesús fuera crucificado junto con otros hace pensar que Pilato debió juzgar varios casos. En los procesos romanos era fundamental la acusación y la defensa del acusado115. Pilato, como prefecto, poséa el derecho de juzgar a los que no eran ciudadanos romanos (los peregrini) de acuerdo con su propio parecer (cognitio extra ordinem) y de dictar, luego, sentencial16. Sólo él podía dictar una sentencia de muerte.

La acusación "hemos encontrado a éste alborotando a nuestra nación, impidiendo pagar tributos al emperador y diciendo que él es el Mesías, el rey", que encontramos sólo en Lucas 23,2 , aunque se debe, probablemente, a la creación literaria de Lucas, sin embargo, "ha dado en la diana, pues desarrolla lo que sugiere, ya sin vacilaciones posibles, el relato de Marcos y confirman los de Mateo y Juan"117. Pero el hecho de que fuera crucificado y la noticia de que, según los evangelistas, indicaba la causa de su condenación ("rey de los judios") hace pensar que los acusadores presentaron a Jesús como revolucionario político que, con su pretensión (mesiánica) de realeza, ponía en peligro la autoridad y legitimidad del gobierno romano. Como señala Légasse118, "semejantes pretensiones suponían un atentado directo contra el Imperio romano y contra su soberano. Caían bajo la acusación de crimen [laesae: el añadido es mío] maiestatis populi romani y, como tal, Llevaba consigo la pena capital". Y que tuvieron éxito en su empresa (el intento de presentar a Pilato, procurando liberar y absolver a Jesús responde, más bien, al intento apologético cristiano de disimular el motivo político por el cual las autoridades romanas condenaron a muerte a Jesús, pues ello complicaba la siluación de las comunidades cristianas dentro del imperio). Jesús, pues, fue condenado por seditio 119 , algo que parece innegable desde el punto de vista histórico. La pretensión de ser "rey de los judíos", que recoge el título de Jesús en la cruz (Mc 15, 26), representaba un peligro grave contra el imperio romano y era reprimida brutalmente120.

114. Op. cir., p. 94. Puede verse, ibid., pp. 94-98, dónde están las inverosimilitudes históricas de los relatos de los cuatro evangelios.

115. Becker, op. cit., p. 430.

116. Así Becker, op. cil, p. 430.

117. Légasse, op. cit., p. 103; cfr. p. 95.

118. Op. cit., p. 105; cfr. pp. 103 s.

119. Así Becker, op. cit., p. 423; Reibold, op. cit., p. 314; Winter, Trial, p. 206. Légasse hace notar, op. cit., p. 105 , n. 62 , que la acusación seria seditio y no perduellio (véanse allí sus razones).

120. Así, Ritt, op. cit, p. 173. 
En cuanto a la comparecencia de Jesús ante Herodes, que sólo narra Lucas 23, 6-12, parece tener razón Légasse121 cuando saca la conclusión "parece muy difícil recoger en la escena en cuestión el eco de un hecho histórico (...) y será una muestra de prudencia dejar al tetrarca fuera del campo de las responsabilidades de la muerte de Jesús".

Podemos concluir, por tanto, que el responsable último $-\mathrm{y}$, en el fondo, definitivo- de la muerte de Jesús fue Pilato como autoridad política máxima en la región, tanto más cuanto que, como hemos visto, sólo él disponía en la provincia romana de Judea de la posibilidad para condenar a alguien a muerte. El que cediera a presiones o manipulaciones de una "clique" saducea122 no cambia el hecho de que fue Pilato el que tomó la decisión última y definitiva. Por otro lado, como se ha notado a menudo, no tiene por qué sorprendemos la colaboración de las autoridades judías con las romanas. Pues, como vimos, se conoce el caso de Jesús, hijo de Ananías, narrado por Josefo en BJ VI, 300-305. Este empeź a gritar contra Jerusalén y el Templo, en la fiesta de las tiendas del año 62: "Voz del oriente, voz del occidente, voz de los cuatro vientos, voz contra Jerusalén y contra el Templo, voz contra el esposo y la esposa (cita Jer 7 , 34 ; $c f$. 16, 9), voz contra todo el pueblo". Las autoridades judías lo detuvieron y, después de interrogarlo, probablemente en el sanedrín, y de hacerle dar una paliza, lo entregaron al procurador Albino. Pero éste, después de flagelarlo, lo soltó por considerar que estaba loco. El parecido con lo que ocurrió con Jesús de Nazaret está en que también aquí un "delito" religioso provocó la detención y el hecho de que lo entregaran a la autoridad romana. La diferencia está en que, al ser un hecho aislado y no tener Jesús, hijo de Ananías, discípulos, le evitó el que acabara crucificado123.

\section{A modo de conclusión}

¿Por qué mataron a Jesús? Porque, como dice Apocalipsis 1, 5, fue el "testigo fiel" del proyecto original de Dios, el que era capaz de realizar en la tierra el reino-reinado de Dios (cfr. Mc 1, 14s; también Lc 4, 16-20, donde Jesús, citando Is 61,12 , habla del "año de gracia" o año jubilar en el cual se redistribuye la tierra).

Cuando Dios se escogió un pueblo particular, el de Israel, precisamente porque era un pueblo injustamente oprimido y lo liberó "con brazo fuerte y mano poderosa" ( $f r$. Dt 26, 5b-10), no lo hizo para darle un "privilegio". Lo escogió para que, mostrando en él y con él su inmensa bondad y misericordia

121. Op. cih, p. 107.

122. Así, Rill, op. cit., pp. 174s.

123. Asi, Reinbold, op. cit., pp. 314-316. 
gratuita, pudiera ver -él y junto con él el resto de los pueblos de la tierra- que Dios no puede "tolerar" -va contra su mismo ser de Padre- la opresión y el empobrecimiento de nadie. Por esto le inculcó -y el testamento de Moisés en el Deuteronomio lo expresa muy bien- que desde su experiencia de liberación debía cumplir el encargo expreso de ser el lugarteniente de Dios -sus brazos- en este mundo ( $c f r$. Dt 15,15 ). Por esto, Dios se reservó la propiedad de la tierra que les daba en usufructo ( $c f r$. Lv 25, 23: "La tierra no puede venderse para siempre, porque la tierra es mía, ya que ustedes son para mí como forasteros y huéspedes"124). La misión del pueblo era, entonces, erradicar la pobreza en Israel ( $c f r$. Dt 15, 4). Y como esto no era una tarea fácil, Dios les da unas leyes que intentarán compensar las disfunciones inherentes al funcionamiento económico ( $c f r$. Lv 25). Con ello, Dios quería mostrar que era posible crear un "estilo altemativo de vida social" que posibilitara una vida digna a las personas que, por distintas causas, eran candidatas claras a la marginación (las viudas, los huérfanos, los emigrantes, etc.: cfr. Dt 14, 28-29; Lv 19, 9-10; Ex 22, 20-26; Ecl. 35, 14-22).

Pero el pueblo se mostró como un pueblo "de dura cerviz". Y el Dios bueno y misericordioso, "que hace obras de justicia y otorga el derecho a todos los oprimidos" (SI 103, 6), que es "clemente y compasivo, tardo a la cólera y lleno de amor" (SI 103, 8), no se cansó de enviarle sus profetas para llamarlos a la conversión. Pero, como nos recuerda la parábola de los pérfidos viñadores ( $c f r$. Mc 12, 1-12), el pueblo escogido no quiso escucharlos y los maltrató.

Ni siquiera cuando vino el Hijo quisieron convertirse. Al contrario, lo mataron ( $c f r$. Mc 12, 6-8). De este modo se convirtió el Hijo en el "Cordero degollado" que el profeta Juan canta en Apocalipsis 5.

Pero ni así logró Dios ablandar el corazón de piedra de una humanidad que sigue sin poder crear unas estructuras políticas, económicas, sociales y religiosas que posibiliten una auténtica justicia y solidaridad universales. Por esto, sigue aumentando el número de los "testigos-mártires fieles", que son asesinados por intentar ser fieles al proyecto de Dios, que tomó carne en Jesús de Nazaret.

Termino este artículo en El Salvador y no puedo menos de recordar, con gratitud, el testimonio de Monseñor Romero, de los mártires de la UCA y de tantas personas, aparentemente anónimas, que con su entrega generosa dieron su vida por una paz con justicia en su país. Su queja ante la injusticia que marca brutalmente nuestro mundo, sigue resonando, como en Apocalipsis 6, 10b-11:

124. Sobre este aspecto, vale la pena leer A. Wénin, "lsrael extranjero y emigrante. El tema de la inmigración en la Biblia", Selecciones de Teologia 35 (1996) pp. 247-256. 
¿Hasta cuándo, Dueño santo y veraz, vas a estar sin hacer justicia y sin tomar vengaza por nuestra sangre de los habitantes de la tierra? Entonces se le dio a cada uno un vestido blanco y se les dijo que esperasen todavía un poco, hasta que se completara el número de sus consiervos y hermanos que iban a ser muertos como ellos.

Ellos, con su testimonio, nos ayudan a comprender mejor por qué mataron a Jesús y quiénes lo mataron. Porque son víctimas de los Imperios opresores, simbolizados por la Bestia del mar (cfr. Ap 13,1-10), y sus aliados ideológicos, simbolizados por la Bestia de la tierra (cfr. Ap 13,11ss), que siguen muriendo y resucitando hasta el día en el cual Cristo juzgue y combata con justicia (cfr. Ap 19, 11-16) y los aniquile definitivamente, a fin de que se instaure "el cielo nuevo y la tierra nueva", en la cual Dios pueda poner su morada y así enjugar toda lágrima, porque ya no habrá ni muerte ni llanto, ni gritos ni fatigas, porque el mundo viejo ha pasado (cfr. Ap 21, 1-4).

Jesús dio su vida para que nunca perdiéramos la esperanza y no cayéramos en la tentación de pensar que no valía la pena intentar convertir en topla su utopía. Y lo mataron -lo matan-todos los que se oponen a este proyecto. 